ISLLAC

Journal of Intensive Studies on Language, Literature, Art, and Culture

Vol. 1 No. 1 September 2017

\title{
THE IMPORTANCE OF ORAL PERFORMANCE: WHAT MAKES A SUCCESSFUL PROFICIENCY-BASED FOREIGN LANGUAGE PROGRAM
}

\author{
Peter Suwarno ${ }^{1}$ \\ Arizona State University \\ peter.suwarno@asu.edu
}

\begin{abstract}
Major Foreign Language (FL) programs in Indonesia, i.e. Indonesian for non-native speakers (BIPA) and English for Indonesian Speakers (EIS), have no standard of assessments on what constitutes a successful program. Some in-country BIPA programs that measure their success using Oral Proficiency Interviews (OPI) show the standard of success in the form of oral proficiency. This paper's purpose is to argue that oral proficiency tests such as OPI is not only a good measure of learners' communicative competence in general, but it also necessitates curriculums, methods, and activities geared toward the better level of communicative proficiency. Therefore, FL learning should emphasize oral proficiency to show a higher level of performable learning outcomes. Based on class observations as well as interviews of BIPA and EIS learners and instructors, this paper shows that lack of oral performance practices and assessments lead to achievement in the target language (TL) knowledge but not the communicative competence. Thus, if communicative competence is the goal, oral proficiency must be the main outcome of any FL programs.
\end{abstract}

Keywords: oral proficiency, communicative competence, language teaching, self-confidence.

\section{INTRODUCTION}

In this globalization era, English has unarguably become the dominant international language commonly used as a lingua-franca and a means of communication among various groups of people all over the world (Crystal 2012). If

\footnotetext{
${ }^{1}$ The author is an Associate Professor of Indonesian Studies at the School of International Letters and Cultures (SILC), at Arizona State University, Tempe, Arizona 85287-0202, USA. 
ISLLAC

Journal of Intensive Studies on Language, Literature, Art, and Culture

Vol. 1 No. 1 September 2017

Indonesia wants to play an important role in the competitive world stage of communication and negotiations, its citizens must master English for the success of its future economically and politically. Countries with better English skills usually have better economies; ${ }^{2}$ and individuals with better English skills usually have higher salaries. ${ }^{3}$ In Indonesia, however, English education has always been challenging both for the instructors as well as for the learners. According to English First's (EF) English proficiency Index, Indonesia is ranked number 32 in terms of the English skills of the population, below Vietnam and Bosnia. ${ }^{4}$

Many have criticized the Indonesian educational systems, curriculums, teachers' lack of competence, and teaching methods which led to the challenge in equipping Indonesian learners with communicative competence in English (Lengkenawati, 2005; Luciana, 2006; Soepriyatna, 2012; Marcellino, 2008; and Sulistiyo, 2016). To compensate the inadequate English education in formal schools, there are private schools and courses in practically every Indonesian city. However, there is no standard measurement of success that determines the levels of learners' proficiency in English. Many of these English programs still emphasize knowledge of English, focusing on grammar and on the use of texts rather than on communicative skills, especially face-to-face oral interaction (Sawir, 2005). This leads to minimal oral proficiency, which in turn, creates lack of communicative confidence in English.

The goal of this study is to argue that the teaching and learning of EFL should emphasize oral proficiency to show the evidence of success and that lack of emphasis on oral proficiency leads EFL teaching programs in Indonesia being viewed as unsuccessful. The evidence for the importance of oral proficiency in the success of foreign language learning will be based on the success of the Indonesian for non-native speakers, known as BIPA (Bahasa Indonesia bagi Penutur Asing), programs that use ACTFL (American Council on the Teaching of Foreign

2 https://hbr.org/2013/11/countries-with-better-english-have-better-economies

3 http://economictimes.indiatimes.com/jobs/those-who-speak-english-fluently-earn-up-to-34-morethan-others-study/articleshow/28426329.cms

${ }^{4}$ Although the description of the statistics makes sense, it should be admitted that this ranking is not based on a reliable data collection method. http://www.ef.co.id/epi/ 
ISLLAC

Journal of Intensive Studies on Language, Literature, Art, and Culture

Vol. 1 No. 1 September 2017

Languages) proficiency guidelines and OPI (Oral Proficiency Interview) tests. This study also argues that emphasizing oral proficiency in language learning is in line with the goals and practices of communicative language teaching (CLT). While studies show that learners' self-confidence correlates with success in achieving foreign language communicative competence (Dörnyei, 2005), other researchers suggest that the oral proficiency-based learning programs help learners build confidence in the oral performance and communicative competence in general. For this purpose, the study will examine data and information on the success of some BIPA programs and compared those with collected information on various English education programs in Indonesia. The study will use previously published statistical data based on OPI pre-tests and post-tests results on some BIPA programs as well as interviews, observation, and personal communication with both learners and instructors of English and of Indonesian.

\section{THE IMPORTANCE OF ORAL PROFICIENCY IN FL LEARNING}

Human language begins as an oral form of communication; almost half of around 7,000 world's languages being used today still do not have any written form. ${ }^{5}$ Learning a foreign language is learning to speak that language since human first learn to speak before learning to use the written forms. Therefore, at least at the earlier stages of learning, speaking is the most important skill of all the four language skills (listening, speaking, reading, and writing), because individuals who learn a language are referred to as the speakers of that language (Ur, 1996). The main aim of English language teaching is to give learners the ability to use English language effectively and correctly in communication (Davies \& Pearse, 2000).

A few scholars agree that oral proficiency is the basis for written proficiency. Sticht \& James (1984:p. 299), for example, argue that: "If reading builds upon a foundation of the person's earlier acquired oral language competence, then it follows that raising the oral language base should elevate reading ability." Similarly, Hiebert, Pearson, Taylor, Richardson, \& Paris (1998: p. 1) argue that: "Oral language is the

${ }^{5}$ https://www.ethnologue.com/enterprise-faq/how-many-languages-world-are-unwritten-0 3 | 
ISLLAC

Journal of Intensive Studies on Language, Literature, Art, and Culture

Vol. 1 No. 1 September 2017

foundation on which reading is built, and it continues to serve this role as children develop as readers." On a similar note, Snow, Burns, \& Griffin (1998: p.108), confirm that: "comprehension of the connected text depends heavily on the reader's oral language abilities, particularly with regard to understanding the meanings of words that have been identified and the syntactic and semantic relationships among them."

Wilkinson (1968) used the term "oracy" to describe the important role of oral language in the development of literacy. According to him, literacy is based on oracy, since an increase in oracy or speaking skill leads to better development of reading and writing skills. Britton (1984) agrees, stating that skills in reading and writing are constructed on speaking skill.

Ability to speak another language is different from having studied another language. It is speaking another language that is frequently associated with many benefits of learning another language. For example, Baker and Westrup (2003) stated that there is a correlation between proficiency in speaking English and better chances of success in individual advancement, including education, jobs, and career.

\section{CLT NECESSITATES ORAL PERFORMANCES}

The suggestion of the above studies that learning a foreign language should emphasize and start with speaking, is compatible with Communicative Language Teaching (CLT), a widely-applauded approach to language teaching, that strongly encourages learners' interactive performances. In Indonesian English classrooms, unfortunately, it is still the instructors who are doing most of the talking, leaving minimal time to the use of TL by the learners.

CLT is teaching-learning activities based on the principle of communicative competence (Savignon, 1983) and on the idea of language as communication (Richards \& Rodgers, 2001). Over the past few decades, CLT is becoming more popular and has been implemented in different parts of the world with different degrees of success. In some cases, it may not be easily implemented, since CLT has its strengths and weaknesses depending on many factors (Pichugova, \& Didenko, 
ISLLAC

Journal of Intensive Studies on Language, Literature, Art, and Culture

Vol. 1 No. 1 September 2017

2016). It is a teaching approach that emphasizes communication as the means and goal of learning, does not emphasize grammatical accuracy, and focuses on learners' conversations about real topics related to their surrounding and experiences using the TL (Savignon, 1997). This learner-centered method, where instructors function as facilitators, is not textbook-centered, but rather focuses on interactional activities and, hence, encourages the development of oral proficiency.

CLT emphasizes meaningful negotiations which enable students to learn and manage their learning process efficiently (Allwright, 1984; Antón, 1999; Englander, 2002; Oxford, 1997). Meaningful interactive learning enhances the creative use of the language, creative classroom activities, and, thus, extensive use of the TL (Brown, 2007). These kind of lively classroom activities that are suited to learners' proficiency levels are expected to enhance learners' motivation (Littlewood, 1981). Learners' motivation to use what they have learned to successfully communicate with other learners in the TL further enhanced their motivation to interact and perform. CLT activities, which encourage natural learning, need performative spontaneity in real life communication that can easily occurred in oral interaction more than in written one.

Communicative competence, which is comprised of grammatical competence, discourse competence, sociolinguistic competence, and strategic competence (Canale \& Swain,1980; Canale, 1983 \& Savignon, 1997; Goh \& Burns, 2012, is more frequently and easily practiced orally than in writings. The sociolinguistic competence of, for example, turn taking and appropriate use of formal versus informal register, and the strategic competence of, for example, negotiating meaning during an interaction are more easily demonstrated through oral communication than in writing. This is why CLT relies much on oral performance activities in classrooms; thus, inevitably emphasize the importance of oral proficiency.

It makes sense that the successful BIPA programs employ CLT, but also usually evaluate learners' achievement in communicative competence using ACTFL proficiency guidelines. ACTFL evaluation uses three modes of communication: interpretive mode, interpersonal mode, and presentational mode (ACTFL, 2012) 
ISLLAC

Journal of Intensive Studies on Language, Literature, Art, and Culture

Vol. 1 No. 1 September 2017

which are reasonably realized in oral performances. The OPI test is one the most popular tests based on ACTFL proficiency guidelines, used to evaluate many abroad programs including Indonesian abroad programs that emphasize oral proficiency.

\section{BIPA PROGRAMS' SUCCESS STORIES}

The important emphasis on oral proficiency-based teaching has shown considerable results in some Indonesian language programs in Indonesia and abroad that underscore oral proficiency. There are three Indonesian abroad program (BIPA) held in Indonesia that have shown a significant degree of success based on ACTFL proficiency guidelines and assessed using OPI tests. They are: the Consortium for the Teaching of Indonesian (COTI) in Salatiga, the Critical Language Scholarship (CLS) in Malang, and Critical Language Institute (CLI) in Bali. Numerous notes and other data have been collected through intensive observations conducted during my service as the Resident Director of these programs: in COTI (2000 \& 2008), CLS (20102012), and CLI (2016-1017).

CLS, COTI, and CLI are in-country Indonesian intensive summer programs funded mostly by the United States government, with a common goal of facilitating the students to achieve better communicative competence in Indonesian. For this reason, these three programs mostly employ communicative approach, with eclectic CLT that emphasizes real life communication (Lee \& Van Patten, 1995). One of the key factors contributing to the success of these programs is that they are immersion programs, requiring active interaction between learners and native speakers (Genesee, 1985). These programs, which run for eight weeks, oblige the learners to live with host families, take extracurricular classes, and have conversation hours with peer tutors, all of whom are required to speak only in Indonesian.

These programs, especially CLS and CLI, measure the success in many different ways, but the most important one is the OPI test that was conducted by the Language Testing International (LTI). The OPI, the validity, and reliability of which have been tested, is a live phone conversation lasting about 30-minute between trained ACTFL certified testers and the learners, to measure oral communicative 
ISLLAC

Journal of Intensive Studies on Language, Literature, Art, and Culture

Vol. 1 No. 1 September 2017

competence. The learners' proficiency and achievement are rated ACTFL proficiency guidelines. Suwarno (2013) showed that, based on the OPI test results, CLS Malang for summers of 2010-2012 was a great success, with many students moving up from novice low to intermediate mid in eight weeks. Data from CLS 2013-2015 also shows similar successful OPI test outcomes (Susanto, 2016). CLI programs in Bali have also shown comparable successful OPI test results (see Appendix C).

There are factors that contributed to the success of these three summer program, especially CLS Malang (Suwarno, 2013) and CLI Bali. First, they have some of the best-selected learners in term of learners' past successes, experience learning another language successfully, being bilingual, and high interest in the host country/culture (Brecht, Davidson, and Ginsberg, 1993). Second, the host institutions have been supportive for the success of the programs with trained instructors, peer tutors, and host families. Third, these instructors and peer-tutors actively participate and focus on the success of the students implementing CLT to improve oral proficiency. Fourth, the enforcement of immersion requires all involved in the program to speak only in the TL. Fifth, the programs enforce the use of descriptive language (the actual Indonesian language use in real communication) and use of authentic materials. Additionally, these programs have a clear standard measure of success, e.g. ACTFL guidelines and OPI tests.

Sixth, the instructors in these three BIPA programs are usually well-trained in communicative approaches with the most current techniques through training conducted prior to the start of each program. In addition, there is monitoring of the instructors' in class activities and the peer-tutors' outside of class activities with the learners. Frequent individual and group meetings with instructors as well as peer tutors to evaluate the teaching-learning are conducted to discuss what works and what does not.

Finally, despite the possible stress of intensive learning in a new culture, the programs and the learners are well funded. Practically all learners received full funding and/or scholarship and they only focus on learning Indonesian and no other compulsory subjects. The institutions, instructors, and staff are relatively well-paid; 
ISLLAC

Journal of Intensive Studies on Language, Literature, Art, and Culture

Vol. 1 No. 1 September 2017

hence, they are willing to spend most of their time and energy for the success of the program and improvement of the learners' oral proficiency.

\section{CHALLENGES OF TEACHING-LEARNING EFL IN INDONESIA}

Based on my experience as the RD of these three BIPA programs, observations of Indonesian EFL classes, and interviews with EFL learners and teachers as well as reviews of studies on the challenges of EFL education in Indonesia, there are three major affective factors (Tallon, 2009) that deserve to be addressed. First, in addition to lack of supportive English speaking community (Sulistiyo, 2016), all of the high school and college students I interviewed have one thing in common about what they said. That is, English learners at high schools and college campuses feel uncomfortable speaking in English for fear of being ridiculed and viewed as weird or arrogant by their peers (see Appendix A. especially \#1 \& 6). This becomes a major barrier of practicing speaking for those who seriously want to improve their oral proficiency, creating a vicious circle between lack of speaking ability and the absence of EFL speaking community (see Appendix A: 3-5).

Second, the above fear leads to apprehension in speaking in English that affects the learners' motivation; such that learners and instructors prefer exercises on readings (Suwir, 2005), grammar and vocabulary, instead of practicing how to speak. The motivation for learning has become to gain knowledge about the TL, thus, preventing learners from obtaining communicative competence.

Third, this embarrassment and apprehension, due to fear of making mistakes and of being ridiculed, can easily lead to lack of self-confidence in using English. This is in contract with the BIPA learners who tend to be eager to participate in trial and error activities, a key ingredient in the success of language learning. As discussed above, lack of self-confidence leads to anxiety which and, henceforth, lack of willingness to participate in classroom spontaneous activities which are essential for a successful implementation of CLT.

Although researchers, e.g. Tallon (2009), argue that the different degrees of individual success of language learning is greatly affected by both affective and 
ISLLAC

Journal of Intensive Studies on Language, Literature, Art, and Culture

Vol. 1 No. 1 September 2017

cognitive domains, the affective factor can be shaped through the participative language learning activities. Brown (2000) argues that the affective aspect or psychological factor deals with personal issues including anxiety, attitude, motivation, emotion, and self-confidence, with self-confidence being the most influential factor affecting language learning.

Djiwandono (2009) agreed that there have been some concerns about Indonesian high school graduates that have no adequate English communicative competence because the English teachers focus on learning about English more than on equipping the students with real communicative skills. The dissatisfaction of English teaching in Indonesian schools lead to the mushrooming number of private courses and programs. However, many of them also emphasize fulfilling specific purposes such as improving grades in school, passing the national exams (UN), or obtaining high TOEFL scores (see Appendix A: 7 \& 10; Appendix B: 11), but not improving learners' real communicative skills. He showed that students' communicative skills are realized in the form of daily casual and broken sentences, not the ones following the pragmatic, linguistics, and grammar rules. Lengkenawat (2005), Luciana (2006), and Soepriyatna (2012), agree with this observation, admitting that the teaching of English in Indonesia is mostly not learner-centered, nor using proficiency-based curriculum as suggested by Celce-Muria, Thurrel dan Dornyei (1995), which at best results in linguistic competence but not communicative competence, especially not oral proficiency.

In the past five years, throughout my visits to Indonesia, I have met many English learners who studied in private courses while also studying English in schools and colleges. Their comments have been in line with other observers concerning the barriers to CLT implementation and to the success of English education in Indonesian, including: lack of learners' motivation, not enough time to practice, resources and materials, and the large number of students in each class (see Appendix B: 6 \& 7)."

\footnotetext{
${ }^{6}$ https:// neeyhapuzee.wordpress.com/2011/08/08/problems-in-teaching-english-as-foreignlanguage-in-indonesia/ 
ISLLAC

Journal of Intensive Studies on Language, Literature, Art, and Culture

Vol. 1 No. 1 September 2017

However, rarely do they mention lack of adequate training and motivation among instructors (Luciana, 2006 \& Lengkenawati, 2005, Sulistiyo, 2008). Instructors should be trained to creatively apply CLT and adjust it to the socio-cultural context of large classrooms. English teachers should be trained to change the cultural concept that teachers are expected to use traditional methods that encourage students' traditional learning styles appropriate to the local customs. It is challenging for Indonesian English teachers to implement CLT while having to creatively use the assigned textbooks, satisfy administrative duties, follow the curriculums, and fulfill the demand of helping the students passed the national examination (see Appendix B). ${ }^{7}$

Another challenge of implementing CLT and emphasizing oral proficiency in Indonesian EFL is lack of self-confidence, just like learners of English from many other language backgrounds (Dörnyei, 2005; Ehrman, 1995; Harmer, 2004). Brown (2001) argues that lack of self-confidence is associated with this anxiety that is shown in the learners' presumption that their speaking in the TL is ungrammatical or incomprehensible. This, according to Horwitz, Horwitz \& Cope (1986), is part of language learning process where learners tend to be self-conscious about their abilities. Horwitz et al. (1986) called this anxiety as "communication apprehension" which they defined as "shyness characterized by fear of or anxiety about communicating with people" (p. 127), mostly due to the possibility of failure or of negative evaluation by others. Dörnyei (2005) argues that anxiety can be beneficial when it produces excitement to act positively, such as work and try hard to succeed; but it can also be damaging when it becomes a barrier to try and perform. Both types of anxiety emerge in all types of language learning process, but the negative one can easily emerge whenever learners try to orally perform in a TL.

CLT may not be suitable for the Indonesian instructors and learners culturally and economically since CLT itself has its own strengths and weaknesses. Richards \& Rodgers (2001) also admit that CLT can have limitations. It is true that

\footnotetext{
7 http:/ / sugengadi.lecture.ub.ac.id/2012/01/communicative-language-teaching-is-it-appropriate-forindonesian-context/
} 
ISLLAC

Journal of Intensive Studies on Language, Literature, Art, and Culture

Vol. 1 No. 1 September 2017

English instructors in Indonesia do not have to strictly follow CLT to be successful, and should creatively employ any methods that work for the circumstances that they are in. However, if communicative competence is still the main goal of English teaching Indonesia, any methods or techniques used must be learner-centered using a proficiency-competence based curriculum (Celce-Muria, Thurrel and Dornyei, 1995) not only linguistic competence but more importantly oral communicative competence.

\section{CLT, ORAL PERFORMANCES AND SELF-CONFIDENCE BUILDING}

Dörnyei (2005) argued that self- confidence is interconnected with selfesteem, attitude toward oneself, and one's perception of his/her own capacity to perform or achieve goals. Harris (2009) confirms that self-confidence constitutes attitudes and beliefs that is shaped throughout one's life through experiential interaction with different people in various social domains.

Self-confidence is central to the success of foreign language learning because it requires a willingness and ability to communicate with other people (Yashima, Zenuk-Nishide \& Shimizu, 2004). Self -confidence helps free oneself from insecurity, uncertainty, fear and social distance (Rubio, 2007) that usually impede active participation in oral performance practice. Thus, oral performance is usually viewed as being highly connected to self-confidence, because self- confidence helps avoid apprehension and enhances learners' active participate in expressing themselves and speaking fluently (Brown,1994) and in actively initiating a communication (Brown 2007).

Therefore, emphasizing oral proficiency in language learning enhances oral performance-related activities which in turn helps build self-confidence. If we want to produce the next generation of confident citizens in English communication, it makes sense to enhance learning English that focuses on oral proficiency. That is why developing oral proficiency with its necessary oral performance practices is very challenging for most instructors. It demands creative communicative activities on the 
ISLLAC

Journal of Intensive Studies on Language, Literature, Art, and Culture

Vol. 1 No. 1 September 2017

part of the instructors, but it requires learners' motivation and willingness to actively participate in the target language communicative activities (Dörnyei, 2001).

Studies by Molberg, (2010), Gregersen\& Horwitz (2002), and Brown (1994) also show learners with self-confident are more willing to take risks and are not afraid of making mistakes when trying to speak a foreign language. Their adventurous tendency urges them to engage in discussion of various topics, learn from mistakes, work hard, and eventually, they increase their oral proficiency.

\section{CONCLUSION}

The success of these BIPA programs cannot be readily duplicated into the existing EFL programs in Indonesia, because they are different in many respects, including the learners' composition and the supporting people or institutions involved. However, there are a few concepts that EFL in Indonesia can learn from these successful BIPA albeit still challenging.

First, learning another language is learning to communicate in the TL which should be realized first and foremost in achieving oral proficiency. Many studies discussed above agree that oral proficiency is the basis for all other skills. All class activities are geared toward speaking activities; most of the reading and writing can be practiced and done outside of class as home works. Exercises on oral performances helps learners enhance their self-confidence that has a wide ranging positive impact on FL learning. It encourages the learners to initiate conversation, actively participate in interactive learning, enhance trial and errors in speaking practices, invite more learners to speak in English, and, thus, lead to the creation of English speaking communities that support EFL.

Second, the standard measure of success (such as ACTFL and OPI), which EFL programs in Indonesia do not have, should be invented, standardized, and implemented. This encourages the creation not only of curriculums, materials, and teaching techniques geared toward meeting the standard but also a community of learners that is concerned about achievements of real communicative competence, 
ISLLAC

Journal of Intensive Studies on Language, Literature, Art, and Culture

Vol. 1 No. 1 September 2017

not just passing the exams. This way, EFL is not about knowledge of English but performable competence in TL communication.

Third, qualified, well-trained EFL instructors are critical to the success of any FL programs. This kind of instructors has confidence in their own oral proficiency and is eager to creatively implement various versions of learners-centered communicative approach that leads to learners' oral proficiency. Graduates of English department should not be certified for teaching English in formal schools and universities unless they have a high level of oral proficiency and showed evidence of creatively using communicative approaches to language teaching.

Fourth, emphasis on oral proficiency must be shown in the learning outcomes which are specific objectives consisting of specific tasks that learners must be able to perform toward the end of each class, week, or course. These outcomes must be contextual, measurable and demonstrable or performable. For beginning Indonesian, for example, learners must be able to perform tasks, such as: introducing one self and others, describing one's family, telling time, making appointments, asking and giving direction, booking a hotel, and describing daily activities. Focusing on learning outcomes, instructors are expected to show the results of the teachinglearning activities in terms of performances, i.e. oral performances.

Finally, emphasizing oral performance and proficiency in the implementation of CLT in Indonesian EFL builds learners' self-confidence. This self-confidence not only enhances learners' motivation to learn and succeed, but also plays a significant role in character building and, thus, in the future success of Indonesia.

\section{REFERENCES}

Allwright, R.L. (1984). The importance of interaction in classroom language learning. Applied Linguistics, 5(2), 156-171.

Antón, M. (1999). The discourse of a learner-centered classroom: Sociocultural perspectives on teacher-learner interaction in the second-language classroom. The Modern Language Lournal, 83(iii), 303-318.

Baker, J., \& Westrup, H. (2003). Essential Speaking Skills: A Handbook for English Language Teachers. London: VSO; New York: Continuum. 
ISLLAC

Journal of Intensive Studies on Language, Literature, Art, and Culture

Vol. 1 No. 1 September 2017

Brecht, R. D., D. Davidson, and R. Ginsberg (1993). Predictors of Foreign Language Gain During Study Abroad. Washington: National Foreign Language Center.

Britton, J. (1984). Viewpoints: The distinction between participant and spectator role language in research and practice. Research in the Teaching of English. 18(3), 320331.

Brown, H. D. (2001). Teaching by principles. New York: Pearson Education. (2007). Teaching by Principles: An Interactive Approach To Language Pedagogy (3rd ed.). New York: Pearson Education, Inc.

Celce-Murcia, Z. Dornyei, S. Thurrel. 1995. Communicative Competence: A Pedagogically Motivated Model with Content Specifications. Issues in Applied Linguistics, 6/2.

Davies, P., \& Pearse, E. (2000). Success in English Teaching. Oxford University Press.

Djiwandono, P. I. (2009). Upaya Bangsa Mempelajari Bahasa Asing: Sejaub Mana dan Mau Kemana? Linguistik Indonesia. 27(1). Jakarta: Masyarakat Linguistik Indonesia.

Dörnyei, Z. (2001). Motivational Strategies in the Language Classroom. Cambridge, UK: Cambridge University Press.

(2005). The Psychology Of The Language Learner: Individual Differences In Second Language Acquisition. New Jersey: Lawrence Erlbaum Associates, Inc.

Ehrman, M. E. (1995). Understanding Second Language Learning Difficulties: Looking Beneath the Surface. Thousand Oaks, CA: Sage.

Englander, K. (2002). Real life problem solving: A collaborative learning activity. English Teaching Forum. 8-11.

Gregersen, T.\& Horwitz, E. (2002), Language Learning and Perfectionism: Anxious and NonAnxious Language Learners. Reactions to their Own Oral Performance. The Modern Language Journal 86 562-570.

Harmer, J. (2004). The Practice of English Language Teaching (6th ed.). Harlow: Pearson Education Limited.

Harris, S. (2009). The Relationship Between Self-Esteem and Academic Success among African American Students in the Minority Engineering Program at a Research Extensive University in the Southern Portion of the United States. Doctoral Dissertation. Louisiana State University.

Hiebert, H., Pearson D., Taylor, B., Richardson, V. \& Paris, S. (1998). Every Child A Reader: Applying Reading Research in the Classroom. Ann Arbor, MI: Center for the

Improvement of Early Reading Achievement (CIERA). http://www.textproject.org/assets/library/resources/Hiebert-PearsonTaylor-Richardson-Paris-1998-Every-Child-A-Reader.pdf

Horwitz, E. K., Horwitz, M. B., \& Cope, J. (1986). Foreign language classroom anxiety. The Modern Language Journal, 70(2), 125-132. 
ISLLAC

Journal of Intensive Studies on Language, Literature, Art, and Culture

Vol. 1 No. 1 September 2017

Lengkenawati, N. S. (2005). EFL teachers' competence in the context of English curriculum 2004: Implication for EFL teacher education. TEFLIN Journal, 16(1), $79-92$.

Littlewood, W. (1981). Communicative Language Teaching: An Introduction. New York: Cambridge University.

Luciana. (2006). Developing standards for language teacher education programs in Indonesia:Professionalizing or losing in complexity. TEFLIN Journal, 7(1), $19-28$.

Marcellino M. (2008). English Language Teaching in Indonesia: A Continuous Challenge in Education and Cultural Diversity. TEFLIN Journal, 19(1): 57-69.

Oxford, R. (1997). Cooperative learning, collaborative learning, and interaction: Three communicative strands in the language classroom. The Modern English Journal, 81(iv): 443-456.

Pichugova, I. L. \& Didenko, A.V. (2016). Post CLT or Post-Method: major criticisms of the communicative approach and the definition of the current pedagogy. SHS Web of Conferences, 01028. https://www.shs conferences.org/articles/shsconf/pdf/2016/06/shsconf_rptss2016_01028.p df

Richards, J. C., \& Rodgers, T. S. (2001). Approaches and Methods in Language Teaching. Cambridge: Cambridge University Press.

Rubio, F. (2007). Self-Esteem and Foreign Language Learning. Cambridge Scholars Publishing. Tallon, M. (2009). Foreign Language Anxiety and Heritage Students of Spanish: A Quantitative Study. Foreign Language Annals, 42(1), 112-137.

Savignon, S.J. (1997). Communicative Competence: Theory and Classroom Practice: Texts and Contexts in Second Language Learning. New York: McGraw-Hill.

Savignon, S. J. (2001). Communicative language teaching for the twenty-first century. In Celce-Murica, M. (Ed.) Teaching English as a Second or Foreign Language (pp.13-28). Boston, MA: Heinle \& Heinle.

Sawir, E. (2005). Language Difficulties of International Students in Australia: The Effects of Prior Learning Experience. International Education Journal, 6 (5): 567 80.

Snow, C.E., Burns, M.S., \& Griffin, P. (Eds.). (1998). Preventing Reading Difficulties in Young Children. Washington, DC: National Academy Press.

Soepriyatna, S. (2012). Investigating and assessing competence of high school teachers of English in Indonesia. Malaysian Journal of ELT Research, 8(2), 3849.

Sticht, T.G., \& James, J.H. (1984). Listening and Reading. In D. Pearson (ed.). Handbook of Research on Reading, vol. 1, pp. 293-317. 
ISLLAC

Journal of Intensive Studies on Language, Literature, Art, and Culture

Vol. 1 No. 1 September 2017

Sulistiyo, U. (2016). English language teaching and EFL teacher competence in Indonesia.

Proceedings of the Fourth International Seminar on English Language and Teaching (ISELT-4).

May 11-12. Padang, West Sumatera, Indonesia.

Susanto, G. (2016). Communicative language teaching and its achievements: a study of in-country program in Indonesia from 2013-2015. LSCAC Conference Proceedings The 4th International Conference on Language, Society, and Culture in Asian Contexts, Volume 2017.

Suwarno, P. (2013). Teaching Descriptive Language for Communicative and Cultural Competence: Learning from CLS Malang In-Country Program 2010-2012. Electronic Lournal of Foreign Language Teaching 10 (Suppl. 1): 264-275

Ur, P. (1996). A Course in Language Teaching: Practice and Theory. Cambridge: Cambridge University Press.

Yashima, T., Zenuk-Nishide,L. \& Shimizu, K. (2004). The Influence of Attitudes and Effect on Willingness to Communicate and Second Language Communication. Language Learning, 54 (1):119-152.

Wilkinson, A. (1968). Oracy in English teaching. Elementary English. 45 (6): pp. 743747.

Appendix A. Students' Comments

The following is a list of most frequently stated comments of EFL students of high schools and colleges.

1. I don't want to speak in English and be ridiculed by my friends.

2. I am not sure if my English is good enough.

3. I do not have anyone to speak in English with.

4. We only speak in English in English class.

5. In English classes we often speak in Indonesian, especially to discuss grammar.

6. We do not want to speak in English and be perceived as arrogant.

7. What is important is that we got good grades.

8. We are not required to always speak in English in class.

9. They don't test our oral proficiency.

10. We just want to get a better TOEFL score for further study.

11. I understand what people say (in English), but I am not comfortable to respond in English.

12. We studied grammar a lot, because the tests are mostly about grammar.

13. We do not have enough speaking practice.

14. I understand what they mean and I know what to say, I just can't say it.

15. I understand reading and writing better.

Appendix B: Instructors Comments 
ISLLAC

Journal of Intensive Studies on Language, Literature, Art, and Culture

Vol. 1 No. 1 September 2017

The following is a list of most frequently stated comments of EFL students of high schools and colleges.

1. We do not have enough time to prepare.

2. Students have to pass the tests and get better grades.

3. We are not trained enough to teach students how to speak.

4. Too much administrative works and reports.

5. CLT? Our students could not actively participate; they tend to be passive.

6. Our classes are too large for CLT.

7. Students do not have the motivation or too shy to speak.

8. We do not have any community that speaks English.

9. They do not have the motivation to obtain communicative competence in English.

10. Students perceived English as one of the most difficult subjects.

11. Speaking English well is not as important as getting a high TOEFL score.

Appendix C: Statistics of the Success of BIPA Programs

1. OPI test results of CLS Malang, summer 2011: This chart was provided by the Council for International Education (ACIE) in Washington, DC. The results of OPI tests for CLS Malang programs from other years (2010-2015) show similar results.

Critical Language Scholarship Program Pre- and Post-Program OPI Scores $(\mathrm{N}=25)$

\begin{tabular}{|l|l|l|l|l|}
\hline Proficiency Level & \multicolumn{2}{l|}{ Pre-Program } & \multicolumn{2}{l|}{ Post-Program } \\
\cline { 2 - 5 } & $\begin{array}{l}\text { Number } \\
\text { of } \\
\text { students }\end{array}$ & $\begin{array}{l}\text { Percent } \\
\text { of } \\
\text { Students }\end{array}$ & $\begin{array}{l}\text { Number of } \\
\text { students }\end{array}$ & $\begin{array}{l}\text { Percent of } \\
\text { Students }\end{array}$ \\
\hline Novice Low & 5 & 20 & 0 & 0 \\
\hline Novice Mid & 10 & 40 & 0 & 0 \\
\hline Novice High & 5 & 20 & 0 & 0 \\
\hline Intermediate Low & 1 & 4 & 0 & 0 \\
\hline Intermediate Mid & 3 & 12 & 5 & 20 \\
\hline Intermediate High & 1 & 4 & 16 & 64 \\
\hline Advanced Low & 0 & 0 & 3 & 12 \\
\hline Advanced Mid & 0 & 0 & 1 & 4 \\
\hline Total & 15 & 100 & 15 & 100 \\
\hline
\end{tabular}

2. OPI test results of CLI Denpasar, Bali, summer 2016 and 2017 combined: This chart was provided by the CLI Arizona State University (ASU).

Critical Language Institute (ASU) Pre- and Post-Program OPI Scores (N=15) 
ISLLAC

Journal of Intensive Studies on Language, Literature, Art, and Culture

Vol. 1 No. 1 September 2017

\begin{tabular}{|l|l|l|l|l|}
\hline Proficiency Level & \multicolumn{3}{|l|}{ Pre-Program } & \multicolumn{2}{l|}{ Post-Program } \\
\cline { 2 - 5 } & $\begin{array}{l}\text { Number } \\
\text { of } \\
\text { students }\end{array}$ & $\begin{array}{l}\text { Percent } \\
\text { of } \\
\text { Students }\end{array}$ & $\begin{array}{l}\text { Number of } \\
\text { students }\end{array}$ & $\begin{array}{l}\text { Percent of } \\
\text { Students }\end{array}$ \\
\hline Novice Low & 11 & 73.4 & 0 & 0 \\
\hline Novice Mid & 0 & 0 & 0 & 0 \\
\hline Novice High & 3 & 20 & 0 & 0 \\
\hline Intermediate Low & 1 & 6.6 & 2 & 13.3 \\
\hline Intermediate Mid & & & 5 & 33.4 \\
\hline Intermediate High & & & 6 & 40 \\
\hline Advanced Low & & & 2 & 13.3 \\
\hline Advanced Mid & & & & 100 \\
\hline Total & 15 & 100 & 15 & \\
\hline
\end{tabular}

